\title{
Contribution of the First Two Years of Post-Neonatal Life to Under Five Morbidity and Mortality at a Tertiary Health Facility
}

\author{
Chukwuemeka Ngozi Onyearugha ${ }^{1}$, Nneka Chioma Okoronkwo ${ }^{1 *}$ and Prince Ezenwa Onyemachi ${ }^{2}$ \\ ${ }^{1}$ Consultant Paediatrician, Senior Lecturer, Department of Paediatrics, Abia State University Teaching Hospital, Aba, Abia State, Nigeria \\ ${ }^{2}$ Consultant Community Physician, Senior Lecturer, Department of Community Medicine, Abia State University Teaching Hospital Aba, Abia \\ State, Nigeria \\ *Corresponding Author: Nneka Chioma Okoronkwo, Consultant Paediatrician, Senior Lecturer, Department of Paediatrics, Abia State \\ University Teaching Hospital Aba. Aba, Abia State, Nigeria.
}

Received: September 19, 2019; Published: October 10, 2019

\begin{abstract}
Introduction: The first two years of life are particularly important as optimal nutrition and care during this period lowers morbidity and mortality. Much has been documented on morbidity and mortality among children aged under- 5 years. This study was aimed at evaluating the contribution of morbidity and mortality in the first 2 years of post-neonatal life to under-5 morbidity and mortality.

Methods: This was a retrospective analysis of all the children aged 29 days to 5 years, admitted into the department of Paediatrics of the Abia State University Teaching Hospital, Aba, over a one-year period.

Results: The total number of children aged 29 days to 5 years, admitted over the study period was 480, out of which those aged 29 days-2years were 346 (72.1\%). There were 300 males and 180 females giving male: female ratio of 1.7:1.

Malaria, acute watery diarrhea and sepsis (35.6\%, 21.3\%, and 18.5\% respectively) were the leading morbidities in those aged 29 days - 5 years. Morbidity was significantly more in the 29 days-2years age bracket, $\mathrm{P}=0.042$. Monthly morbidity was significantly more in the 29 days - 2years age group, than the 29 days - 5years age bracket. $\mathrm{P}=0.000$. Two hundred and eighty-eight (83.2\%) of those aged 29 days-2 years and 412(85.5\%) of those aged 29 days-5years, respectively, were discharged; while their case fatalities were $12.4 \%$ and $9.8 \%$ respectively with no significant difference in their admission outcome. $\mathrm{P}=0.081$.

Conclusions: The contribution of morbidity in the 29 days - 2years age group is significantly high in the overall 29 days-5years age group morbidity. Measures taken to curb morbidity in the under- 2 age group could impact positively on the health status of all children.

Keywords: Contribution; Under-2years; Morbidity; Mortality; Under-5years
\end{abstract}

\section{Introduction}

Much has been documented on prevalent diseases, causes of death and mortality rates in children aged 5 years and below. However, there has not been a delineation regarding the contribution of morbidity and mortality in children aged under- 2 years of life, to the overall under-5 morbidity and mortality.

The first two years of life is the period of greatest neuronal development in the human body with four-fifth of brain development occurring within this period [1]. UNICEF states that the first 8 years of life are the formative years in terms of intelligence, personality and social behavior, with the first two years being crucial [2]. It therefore follows that adequate child health and development within the first two years of life contributes largely to man's survival.
Infant and young child feeding is a key area to improve child survival and promote healthy growth and development [3]. The first two years of life are particularly important as optimal nutrition during this period lowers morbidity and mortality, and also reduces the risk of chronic diseases while fostering better overall development [3].

It is therefore pertinent to evaluate some measure of health in the first two years of life by the morbidity and mortality in that age bracket in relation to under-5 morbidity and mortality.

Findings in this survey would highlight the nature and magnitude of morbidity and mortality in this age group in relation to under five morbidity and mortality. It will also be a veritable tool to determine measures to prevent morbidities thereby enhancing the health and overall development of man. 


\section{Subjects and Methods}

This was a retrospective review of the medical records of all the children aged 29 days to 5 years, admitted into the Children's Emergency Room (CHER) and the Paediatrics Wards of the department of Paediatrics of Abia State University Teaching Hospital (ABSUTH), Aba, from $1^{\text {st }}$ January 2016 to $31^{\text {st }}$ December 2016.

ABSUTH was formerly a general hospital which was converted to a Teaching Hospital in 1994 under the Abia State University. It is located in the densely populated and commercial city of Aba, about 45 kilometers south of Umuahia, the capital of Abia State. It is a tertiary healthcare establishment serving the state and receiving referrals from the surrounding states of Akwa-Ibom, Rivers and Imo.

The Department of Paediatrics is manned by 6 consultants, 12 registrars and 10 house officers (who do 3 monthly rotation before proceeding to other departments).

Children aged 28 days and below are admitted straight into the newborn unit, while those aged 29 days and above are admitted into either CHER or the Paediatrics Ward, depending on the severity of illness. All cases of admission were reviewed by the registrar on call at presentation to the hospital. Diagnosis was made on patients based on clinical features and laboratory results.

The admission registers of CHER and Paediatrics Ward were perused, and the documented admissions had their folders retrieved from the Medical Records Department. Information extracted from the folders included the age, gender, diagnosis, duration and outcome of admission of children aged 29 days to 2 years and also those aged 29 days to 5 years. The total number of admissions in each category was calculated and analyzed.

- Inclusion criteria: Children aged 29 days to 2 years and those aged 29 days to 5 years.

- Exclusion criteria: Children with surgical conditions, those aged above 5 years, those aged below 29 days and those with inadequate data.

- Ethics: Ethical clearance was obtained from the Ethics Committee of the Abia State University Teaching Hospital, Aba, prior to commencement of the study.

- Data Analysis: Data collected were analyzed with Statistical Package for Social Sciences (SPSS) version 22.0. Frequency tables, means and percentages were generated for all variables of interest. Comparisons between variables were done using the Pearson Chi Square test. A confidence interval of 95\% was used, and for all analyses, p-value < 0.05 was taken as statistically significant.

\section{Results}

A total of 520 children aged 29 days to 5 years were admitted over the study period out of which 40 had inadequate data and were therefore discarded. Therefore, 480 were used for further analysis. Children aged 29 days to 2 years constituted 346 (72.1\%) of this number. The total study population (29 days to 5 years) showed 300 males and 180 females, giving male: female ratio of a 1.7: 1 . For those aged 29 days- 2 years, there were 207 males and 139 females, giving male: female ratio of 1.5: 1 .

Malaria, acute watery diarrhoea, sepsis and bronchopneumonia (35.6\%, 18.5\%, 21.3\% and $12.1 \%$ respectively) were the leading diseases in 29 days to 5 years age bracket with ailments occurring more significantly in 29 day to 2 years age category. $\mathrm{P}=0.042$. This is shown in table 1 below.

\begin{tabular}{|l|c|c|c|}
\hline \multicolumn{1}{|c|}{ Diagnoses } & $\begin{array}{c}\text { No in 29 } \\
\text { days- 2 } \\
\text { years }\end{array}$ & $\begin{array}{c}\text { No in 29 } \\
\text { days-5 } \\
\text { years }\end{array}$ & $\begin{array}{c}\text { Percentage (\%) } \\
\text { constituted by the } \\
\text { 29 days-2 years }\end{array}$ \\
\hline Malaria & 113 & 171 & 66.1 \\
\hline Sepsis & 71 & 102 & 69.6 \\
\hline $\begin{array}{l}\text { Acute watery } \\
\text { diarrhoea }\end{array}$ & 78 & 89 & 87.6 \\
\hline Bronchopneumonia & 54 & 58 & 93.1 \\
\hline Meningitis & 7 & 12 & 100 \\
\hline $\begin{array}{l}\text { Protein energy } \\
\text { malnutrition }\end{array}$ & 6 & 6 & 83.3 \\
\hline Dysentery & 5 & 6 & 16.7 \\
\hline Pharyngitis & 1 & 6 & 20 \\
\hline Sickle cell disease & 1 & 5 & 100 \\
\hline $\begin{array}{l}\text { Congenital heart } \\
\text { disease }\end{array}$ & 4 & 4 & 50 \\
\hline $\begin{array}{l}\text { Congestive cardiac } \\
\text { failure }\end{array}$ & 1 & 2 & 26.3 \\
\hline Orbital cellulitis & 1 & 1 & 500 \\
\hline Acute kidney injury & 1 & 2 & \\
\hline Others & 5 & 19 & \\
\hline
\end{tabular}

Table 1: Distribution of diseases in the 29 days -2 year and 29 days -5 year age brackets.

Table 2 demonstrates the monthly admissions over the year of study. The month of February recorded the greatest number of admission in the 29 days - 5 years age bracket with $77(88 \%)$ being in the 29 days- 2 year age category. Also the monthly admissions were significantly more in 29 day-2 year age bracket. $\mathrm{P}=0.000$.

Table 3 demonstrates the outcome of admissions of the patients. Two hundred and eighty eight $(83.2 \%)$ of the patients in the 29 days-2 year age group were discharged whereas $412(85.8 \%)$ of the 29 days-5year age-bracket were similarly discharged. Case fatalities were $12.4 \%$ and $9.8 \%$ in the 29 days- 2 years and 29 days5 years age groups respectively. There is no significant difference in the outcome of admissions between the two groups. $\mathrm{p}=0.332$. 


\begin{tabular}{|l|c|c|c|}
\hline \multicolumn{1}{|c|}{ Month } & $\begin{array}{c}\text { 29days- } \\
\text { 2year } \\
\text { admission }\end{array}$ & $\begin{array}{c}\text { 29 days- } \\
\text { 5 year } \\
\text { admission }\end{array}$ & $\begin{array}{c}\text { Percentage (\%) } \\
\text { contribution of those } \\
\text { aged 29 days-2 year }\end{array}$ \\
\hline January & 35 & 39 & 89.7 \\
\hline February & 77 & 88 & 87.5 \\
\hline March & 27 & 38 & 71.1 \\
\hline April & 30 & 33 & 90.9 \\
\hline May & 20 & 24 & 88.3 \\
\hline June & 37 & 42 & 88.1 \\
\hline July & 24 & 26 & 92.3 \\
\hline August & 37 & 40 & 92.5 \\
\hline September & 36 & 40 & 90.0 \\
\hline October & 18 & 25 & 72.0 \\
\hline November & 26 & 37 & 70.3 \\
\hline December & 27 & 32 & 84.4 \\
\hline
\end{tabular}

\begin{tabular}{|l|c|c|c|c|}
\hline $\begin{array}{c}\text { Outcome } \\
\text { of } \\
\text { admission }\end{array}$ & $\begin{array}{c}\text { No in 29 } \\
\text { days- } \\
\text { 2years age } \\
\text { group }\end{array}$ & $\begin{array}{c}\text { Percent- } \\
\text { age (\%) }\end{array}$ & $\begin{array}{c}\text { No in 29 } \\
\text { days- } \\
\text { 5years age } \\
\text { group }\end{array}$ & $\begin{array}{c}\text { Percent- } \\
\text { age (\%) }\end{array}$ \\
\hline Discharge & 288 & 83.2 & 412 & 85.8 \\
\hline Dead & 43 & 12.4 & 47 & 9.8 \\
\hline DAMA & 10 & 2.9 & 10 & 2.1 \\
\hline Referred & 5 & 1.5 & 6 & 1.3 \\
\hline Absconded & 0 & 0.0 & 5 & 1.0 \\
\hline Total & 346 & 100 & 480 & 100 \\
\hline
\end{tabular}

Table 3: Outcome of admission in the 29 days-2 years and 29 days -5 years age brackets.

Table 4 showed that Malaria, sepsis, acute watery diarrhea were the leading causes of mortality in the 29 days-5years age group with no significant difference compared to those aged 29 days- 2

Table 2: Monthly distribution of admissions in the 29 days -2 year and 29 days -5 year age brackets. years. $\mathrm{P}=0.081$.

\begin{tabular}{|l|c|c|c|c|}
\hline Causes of mortality & $\begin{array}{c}\text { No in 29 days-2 } \\
\text { years age group }\end{array}$ & $\begin{array}{c}\text { No in 29 days-5 } \\
\text { years age group }\end{array}$ & $\begin{array}{c}\text { Percentage in the 29 } \\
\text { days-2 years age group }\end{array}$ & $\begin{array}{c}\text { Percentage in the 29 } \\
\text { days-5 years age group }\end{array}$ \\
\hline Malaria & 15 & 16 & 34.9 & 34.0 \\
\hline Sepsis & 14 & 15 & 32.6 & 31.9 \\
\hline A W D & 6 & 7 & 14.0 & 14.9 \\
\hline BPN & 2 & 2 & 4.7 & 4.3 \\
\hline Meningitis & 2 & 2 & 4.7 & 4.3 \\
\hline PEM & 2 & 2 & 4.7 & 2.1 \\
\hline AKI & 1 & 1 & 2.3 & 2.1 \\
\hline H W S & 1 & 1 & 2.3 & 2.1 \\
\hline ALL & 1 & 1 & 2.3 & 100 \\
\hline Total & 43 & 47 & 100 & \\
\hline
\end{tabular}

Table 4: Causes of death in the 29 days- 2 years and 29 days- 5 years age categories.

AWD: Acute watery diarrhea; BPN: Bronchopneumonia; PEM: Protein energy malnutrition; AKI: Acute kidney injury; HWS: Hypoglycaemia with seizure; ALL: Acute lymphoblastic leukemia.

\section{Discussion}

Malaria, acute watery diarrhea and bronchopneumonia constituting major morbidities in under-5 children of sub-Saharan Africa as noted in our study has been vastly reported [4-6].

Also, that morbidity in the 29 days- 2 year age bracket is significantly more than that of 29 days -5 year age group as revealed in our study, has been noted in a previous publication [5]. These observations could be explained as follows: The first two years of life is when maternal immunity in the child wanes and the child's own immunity is yet to mature $[7,8]$. It is a period when crawling and other exploratory activities begin and supervision by the caregivers begins to drop. Overcrowding, poor environmental sanita- tion, ignorance, poverty, poor health seeking attitude of parents in developing countries 9,10 of which Nigeria is one, contribute significantly to morbidity in the very young child. The combination of these factors makes the under- 2 more susceptible to infectious diseases.

Our study also revealed that admissions in the 29 days- 2 year age group were significantly more than in the overall 29 days5 year age group. It has been noted previously that admissions among under-fives were significantly more in the under-two [5].

The surge in the frequency of admissions in the month of February may not be readily explained. It might be due to the citizenry misconstruing free of charge treatment introduced for surgical 
conditions by the Teaching Hospital during that period. ABSUTH wanted to boost the record of complex surgeries performed in the Obstetrics and Gynaecology and Surgery departments for accreditation purposes. This offer was applicable to all categories of patients encouraging even the caregivers of very ill children to present them in greater numbers. Those with medical, non-surgical conditions, also presented en-mass to ABSUTH.

It was also noted in our analysis that significantly more children aged 29 days-2 years were admitted monthly. This could be explained by the fact that the factors responsible for their greater vulnerability to disease were already there all through the months.

Our study revealed that the outcome of admissions between the 29 days- 2 year and 29 days- 5 year age brackets is not statistically significant. However, a previous report indicated that morbidity and mortality were significantly more in children aged less than 2 years than those under five years [5]. The morbidity in this study being significantly more in the 29 days- 2 years age bracket than the 29 days- 5 year age group, while the mortality is not, is in contrast with a previous report where mortality was also significantly higher [5]. This might probably be explained by better management approach in terms of equipment and drugs now more available than forty years ago when the study was conducted [5]. It could also be that the circumstances which predisposed these children to morbidity have not significantly improved. Measures that can be taken to strengthen the immune status of these children as well as limit their exposure to infectious agents should be enhanced. These measures include exclusive breast feeding, routine immunization and maintenance of environmental sanitation $[9,11,12]$.

Our report that malaria, sepsis and acute watery diarrhea were the leading causes of mortality in the two age groups contrasts with the study at Benin where acute respiratory disorders and gastroenteritis were the major causes of mortality, excluding malaria. In our study, malaria constituted $34.9 \%$ and $34 \%$ of mortality in the 29 days- 2 year and 29 days- 5 year age brackets respectively. Though there is no significant difference in the mortality secondary to malaria, it is quite high and this could be explained by the fact that malaria also constituted the major morbidity in both age brackets. Also, Nigeria lies in the holoendemic zone of malaria transmission [13], hence the high level of morbidity and mortality from malaria noted in our study. Prompt treatment of malaria in children below 5 years, with febrile convulsion cannot be overemphasized [14]. The Benin study could have contrasted with ours in registering lower morbidity due to malaria. This is probably because they included neonates in the study. Neonates constitute a significant proportion of under-five morbidity and mortality with high occurrence of gastroenteritis and respiratory infections. That study was done particularly in the era when exclusive breast feeding was not in practice.

\section{Conclusion}

The contribution of morbidity in children aged 29 days-2 years is significantly high among the overall 29 days- 5 year age category. Measures aimed at curbing morbidity in them such as exclusive breastfeeding, ensuring regular immunization, maintenance of sanitary environment, prompt diagnosis and treatment of any illness, could go a long way in improving their health. These will enhance the overall health status of the child.

\section{Recommendations}

1. More attention should be paid to the under-2 age groups because they contribute significantly to under-5 morbidity and mortality.

2. Breastfeeding of children up to the age of 2 years should be encouraged where possible.

3. Effort should be geared towards health education of the populace on basic malaria control measures such as disposing of water containing vessels from the environment, use of insecticide treated bed nets and prompt treatment of malaria in children aged less than 5 years with febrile illness.

4. The government should be encouraged to provide properly staffed and equipped health centres in close proximity to people's residence. They should also provide free medical treatment in government health facilities for children aged below 5 years.

\section{Funding}

None.

\section{Conflict of Interest}

Authors have nothing to declare.

\section{Acknowledgement}

Our profound gratitude goes to the nursing staff of the Children Emergency Room, Main Paediatrics Wards and staff of the Medical Records Department for their cooperation during data collection.

\section{Authors' Contribution Details}

- Onyearugha C N conceived and designed the manuscript, helped in acquisition of data, analysis and interpretation of data, and also wrote the manuscript.

- Okoronkwo N C contributed in the design and revision of the manuscript and gave final approval of the version to be published.

- Onyemachi PEN helped with acquisition of data and interpretation of the analyzed data, edited the manuscript and gave final approval of the version to be published. 


\section{Bibliography}

1. Tierney AL and Nelson CA. "Brain Development and the Role of Experience in the Early Years". Zero Three 30 (2009): 9-13.

2. Early childhood development/UNICEF.

3. Moghaddam TH., et al. "Infant and Young Child Feeding: a Key area to Improve Child Feeding: a Key area to Improve Child Health". International Journal of Pediatrics 3 (2015): 10831092.

4. Lugangira K., et al. "Morbidity and mortality of children aged 2-59 months admitted in the Tanzania Lake Zone's public hospitals: a cross-sectional study". BMC Research Notes (2017).

5. Obi J 0. "Morbidity and Mortality of Children Under Five Years Old in a Nigerian Hospital". Journal of the National Medical Association 71 (1979): 245-247.

6. Eseigbe EE., et al. "Febrile seizures in Kaduna, north western Nigeria". Nigerian Medical Journal 53 (2012): 140-144.

7. Waaijenborg S., et al. "Waning of Maternal Antibodies Against Measles, Mumps, Rubella, and Varicella in Communities with Contrasting Vaccination Coverage". The Journal of Infectious Diseases 208 (2013): 10-16.

8. Georgountzou A and Papadopoulos NG. "Postnatal Innate Immune Development: From Birth to Adulthood". Frontier in Immunology (2017).

9. Feachem RG., et al. "Sanitation and disease. Health aspects of wastewater and excreta management". Chichester: John Wiley and Sons; (1983): 326.

10. Bishwajit G., et al. "Social Determinants of Infectious Diseases in South Asia". International Scholarly Research Notices (2014).

11. Turin CG and Ochoa TJ. "The Role of Maternal Breast Milk in Preventing Infantile Diarrhea in the Developing World". Current Tropical Medicine Reports 1 (2014): 97-105.

12. Linda L and Bellig RN. "Immunization and the Prevention of Childhood Diseases”. JOGNN 24 (1995): 669-677.

13. Ukpai OM and Ajoku EI. "The prevalence of malaria in Okigwe and Owerri areas of Imo state". Nigerian Journal of Parasitology 22 (2001): 43-48.

14. Fischer PR and Bialek R. "Prevention of Malaria in Children". Clinical Infectious Diseases 34 (2002): 493-498.

Volume 2 Issue 11 November 2019

(C) All rights are reserved by Chukwuemeka Ngozi

Onyearugha., et al. 